\title{
SEASONAL DYNAMICS OF PARASITOSES IN GRASSCARP (CTENOPHARYNGODON IDELLA) FRY AND FINGERLINGS
}

\author{
J. WILLOMITZER
}

Veterinary Research Institute, 62132 Brno

Received March 27, 1980

\begin{abstract}
Willomitzer, J.: Seasonal Dynamics of Parasitoses in Grasscarp (Ctenopharyngodon idella) Fry and Fingerlings. Acta vet. Brno, 49, 1980: 269-277.

Examination of grasscarp (Ctenopharyngodon idella) fry and fingerlings from the State Fishery, Pohořelice, for 3 years revealed grasscarp infestation with 12 parasite genera or species. The intensity and extensity of infestation was highest in the period August to October. The parasites involved were Chilodonella cyprini, Trichodinella sp. and Trichodina domerguei f. magna, which were found from 1 week after hatching, and Diplostomum sp., Ichthyophthirius multifiliis, Dactylogyrus sp., Diplozoon paradoxum, Cryptobia branchialis, Eimeria sp., Piscicola geometra and Nematoda sp., which were demonstrated in grasscarp fingerlings. Moreover, there were a few findings of Cysticercus Gryporhynchus cheilancristrotus which confirmed a previous observation. Age-dependence of the intensity and extensity of infestation was apparent particularly in Diplostomum metacercariae where the rate of infection was $100 \%$ from 9 weeks of age and the number of parasites per host rose with advancing age from 1.4 at 3 weeks to 34.7 at 16 weeks. The intensity and extensity of Diplostomum metacercariae infection in grasscarp was related to the intensity and extensity of infestation with Diplostomum cercariae in intermediate host snails.

Intensity and extensity of infestation, Cryptobia branchialis, Eimeria sp., Chilodonella cyprini, Icnthyophthirius multifiliis, Trichodina domerguei f. magna, Trichodinella sp., Dactylogyrus sp., Diplozoon paradoxum, Cysticercus Gryporhynchus cheilancristrotus Diplostomum sp., Nematoda sp., Piscicola geometra.
\end{abstract}

A considerable rise in the production of herbivorous fish will probably be one of the tasks facing state fisheries in the next five-year-plans in Czechoslovakia. A prerequisite for this is the introduction of artificial spawning. The role which herbivorous fish play in the production of animal protein emerges, among other things, from the data on good economic results in the neighbouring countries (Dyk 1973).

After herbivorous fish from the Amur area of the USSR and China were acclimatized to the conditions of the European part of the USSR and other socialist countries, the breeding problems and fish disease control came to the fore (Lu cký 1968). It became clear that the grasscarp (Ctenopharyngodon idella) harbours a number of parasites (Musselius 1966, 1969; Ivasik and Kulakovskaja 1968; Lucký 1968; Klenov 1971; Migała 1971; Mészároš 1971; Žitňan 1971; a. o.). Several studies have been published on the most important parasitic diseases of herbivorous fish such as cryptobiosis (Brichuk 1969), diplostomosis (Molnár 1974, Kozák and Žitňan 1974, Havránek 1978), botriocephalosis (Klenov 1971), ichtiophthiriasis (Ivasik und Karpenko 1966) and dactylogyrosis (Agapova and Akhmetova 1966).

The present study was designed to investigate the infestation of grasscarp fry and fingerlings and to elucidate the seasonal dynamics and pathogenesis of the individual parasite species involved. 


\section{Materials and Methods}

The examinations were conducted on grasscarp fry and fingerlings reared in nursery and fingerling ponds of the State Fishery at Pohořelice during a 3-year period. The fry were reared up to 3 weeks of age in monoculture in nursery ponds circa $2500 \mathrm{sq} . \mathrm{m}$ in area and then moved to fingerling ponds circa 40000 sq. $\mathrm{m}$ in area where they were reared in polyculture (together with silver carp, common carp, tench and other fish species) till they were transferred to storage ponds. All the fingerling ponds were supplied with water from the river Jihlava. The nursery and fingerling ponds were treated with chlorinated lime at $200 \mathrm{~kg}$ per $2500 \mathrm{sq}$. m each time after the rearing was completed and the fish were caught. After being refilled with water, the fingerling ponds were fertilized with swine slurry in two 10001 doses given one week apart. The water temperature of the ponds in summer months (July, August) ranged between 19 and $24{ }^{\circ} \mathrm{C}$. Samples of the grasscarp fry and fingerlings were taken in groups of 18 to 53 specimens at 1 to 35 weeks of age.

At the laboratories of the Veterinary Research Institute, Brno, the grasscarp fry and fingerling specimens were measured and weighed and their skin, blood, gills, liver, kidney, intestines and ocular lens examined according to Lucký (1976). The infestation was evaluated in terms of extensity (i. e. percentage of grasscarp infected) and intensity (parasite number in individual infected grasscarp for protozoa or mean parasite number per host for helminths). The number of protozoa in individual hosts was assessed on the basis of protozoa seen in the microscopic field using a + to +++ scale where,+++ and +++ indicate solitary protozoa, more than 10 protozoa and more than 100 protozoa, respectively. Examination for blood parasites was supplemented by staining with May-Grünwald-Giemsa (Jírovec 1948). Moreover, the silvering method was used particularly for Trichodinella sp. and Trichodina sp. (Lucký 1976).

To investigate the relation between Diplostomum metacercariae infection of fish and intermediate host snails, groups of various snail species were collected during the study and were examined for the presence of Diplostomum cercariae. The cercariae thus obtained were used for experimental infection of fish of the species Lebistes reticulatus. Species determination of Diplostomum metacercariae was carried out by means of the silvering method according to Havránek (1978). Species determinations of the other parasites were carried out according to Bychovský et al. (1962).

\section{Results}

The examination of grasscarp fry and fingerlings from nursery and fingerling ponds of the State Fishery at Pohořelice for 3 years revealed the presence of the following 12 parasites in the organs given below in the brackets:

\section{Cryptobia branchialis}

Eimeria sp.

Chilodonella cyprini

Ichthyophthirius multifiliis

Trichodina domerguei f. magna

Trichodinella sp.

Dactylogyrus sp.

Diplozoon paradoxum

Cysticercus Gryporhynchus cheilancristrotus

Diplostomum sp.

Nematoda sp.

Piscicola geometra (gill)

(intestine)

(skin)

(gill)

(gill, skin)

(gill, skin)

(gill)

(gill)

(intestine)

(eye)

(intestine)

(skin)

Infestation of grasscarp fry reared in monoculture in nursery ponds from 1 to 3 weeks after hatching was first observed at 1 week of age, at which time Chilodonella cyprini, Trichodinella sp. and Trichodina domerguei f. magna were demonstrated. At 3 weeks of age the fry were parasitized in addition particularly with Dactylogyrus sp. and Diplostomum metacercariae.

Fingerlings 4 weeks and older in age reared in polyculture in fingerling ponds harboured also Eimeria sp. and Piscicola geometra. 
Fingerlings aged 35 weeks were infested in addition with Diplozoon paradoxum, Nematoda sp. and Cysticercus Gryporhynchus cheilancristrotus (Wedl, 1855). The last-named findings were rather rare and are a confirmation of previous observations made in the same area (Tománek 1952) (Fig. 1).

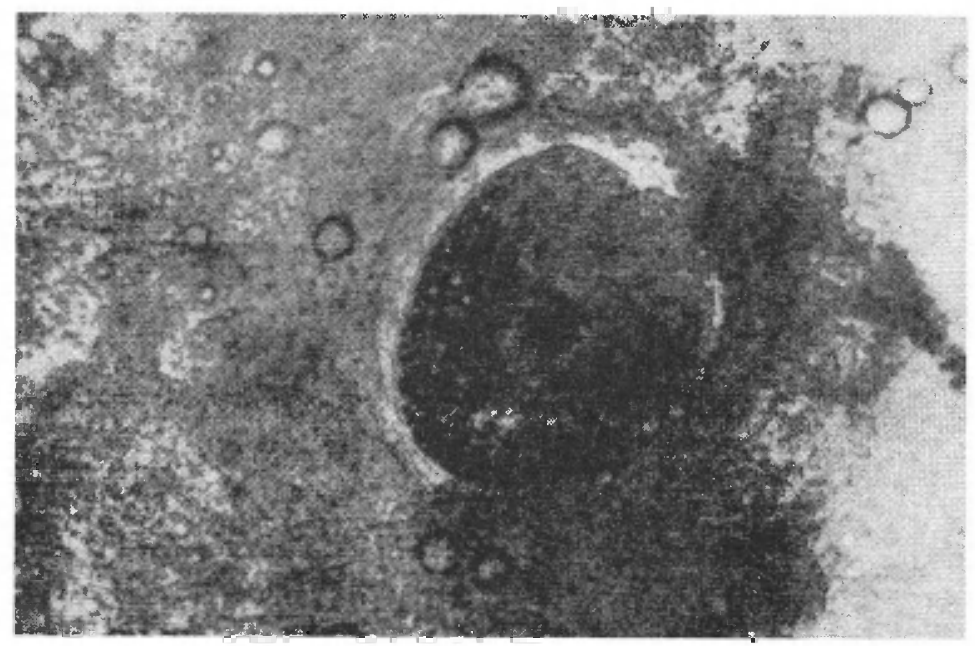

Fig. 1.

Cysticercus Gryporhynchus cheilancristrotus. $(\times 35)$

Evaluation of the involvement of the individual genera in the infestation of grasscarp fry and fingerlings at various ages (Tables 1 and 2) shows that Cryptobia sp. and Eimeria sp. were found only in fingerlings aged 35 and 11 weeks, respectively, and that the intensity of infestation with these parasites was low. Chilodonella cyprini, on the other hand, were abundant in fingerlings aged 16 and 35 weeks where the percentage of infected fingerlings amounted to 24.1 and 55.6 per cent, respectively. Ichthyophthirius multifiliis was found only in one fingerling, and then only as a solitary finding.

Trichodina sp. and Trichodinella sp. were found very frequently and in high numbers. The infestation with these two related genera was apparently not age-dependent, since Trichodinella sp. was found in almost all age groups, with the extensity of infestation ranging between 13.8 and 100.0 per cent. Dactylogyrus sp. was found mainly in grasscarp fingerlings aged 3,4,16 and 35 weeks; the extensity of infestation was highest $(57.7$ per cent) at 3 weeks and the number of parasites per host was highest (6.2) at 35 weeks of age.

Diplozoon sp., Cysticercus Gryporhynchus cheilancristrotus, Nematoda sp. and Piscicola geometra were found almost exclusively in grasscarp fingerlings aged 35 weeks.

Age-dependence of the extensity and intensity of infestation was apparent particularly in Diplostomum metacercariae which were first observed in grasscarp fingerlings at 3 weeks of age. The extensity of infestation with parasite rose steadily 


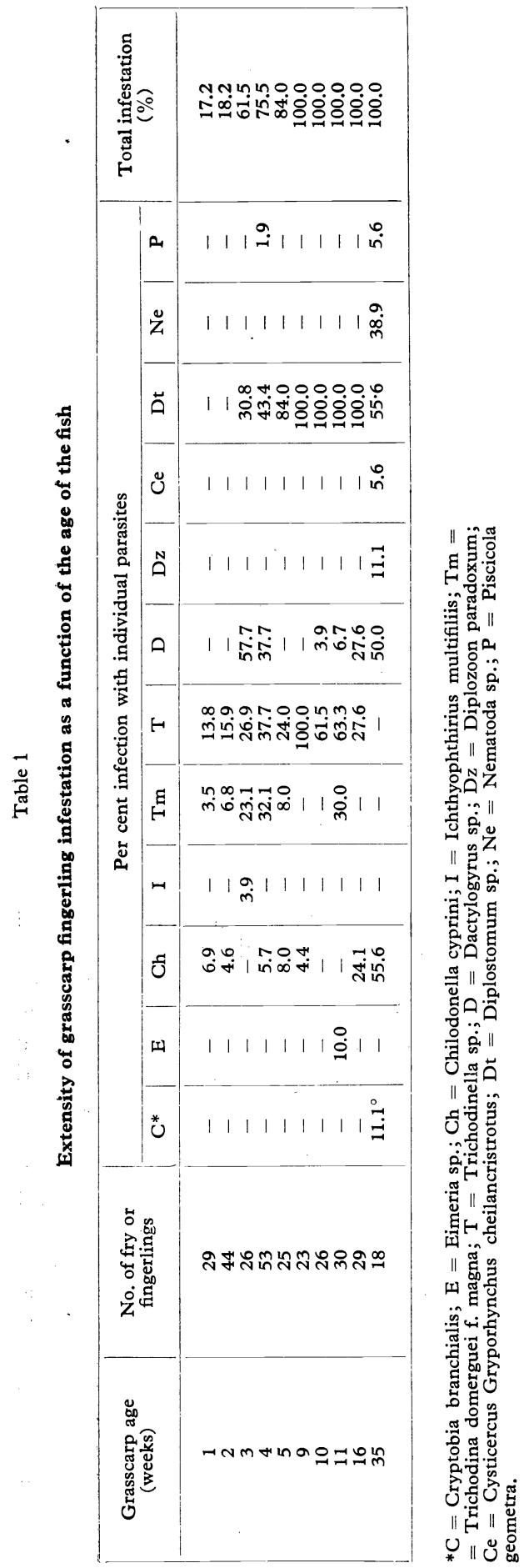

from 30.8 per cent at 3 weeks to 84.0 per cent at 5 weeks, reached 100 per cent at 9 weeks of age and continued at the same level till 16 weeks of age. The mean number of parasites per host rose from 1.4 at 3 weeks to 34.7 at 16 weeks of age (Table 2).

Examination of intermediate host snails for Diplostomum cercariae during the period May to October showed the highest rate of infestation (62.5 to 100 per cent) in August (Table 5), i. e. at the time that the rearing of grasscarp fry was in progress. The highest infestation rate of snails in October $(80$ to 100 per cent) coincides with the highest infestation (100 per cent) of grasscarp fingerlings. In this connexion it is of interest to note that attempts at experimental infection of experimental fish were most (80 and 50 per cent) successful in August and October. It can therefore be concluded that the high infestation of intermediate host snails with Diplostomum sp. cercariae in August to October in the field is responsible for the high infestation rate in fish during this period.

To find whether one or more species of the genus Diplostomum are involved in the infestations, the metacercariae were examined for the location and number of calcium bodies: Only one specimen showed a different distribution of these bodies (Fig. 2 and 3). This cannot be regarded as evidence that two species were involved; it may well be that the metacercaria in question was of different age.

Investigation of seasonal trends in the infestation of grasscarp fry and fingerlings (Tables 3 and 4) showed that the extensity and intensity of infection with Eimeria sp. were highest in October. Similarly, the extensity and intensity of infection with Chilodonella cyprini, Trichodina domerguei f. magna, Trichodinella sp., Dactylogyrus sp. and Diplostomum metacercariae were highest in August to October. 


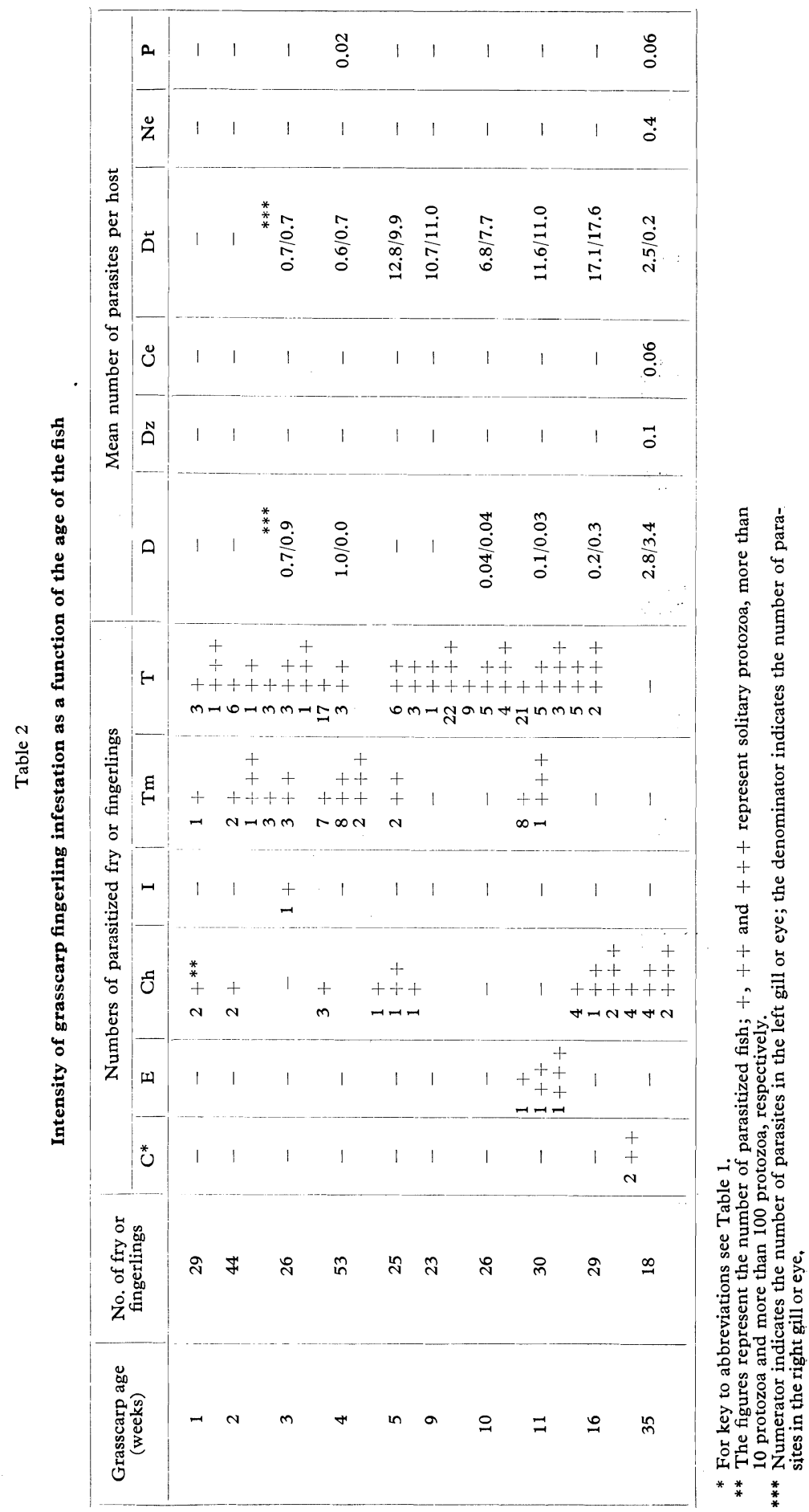



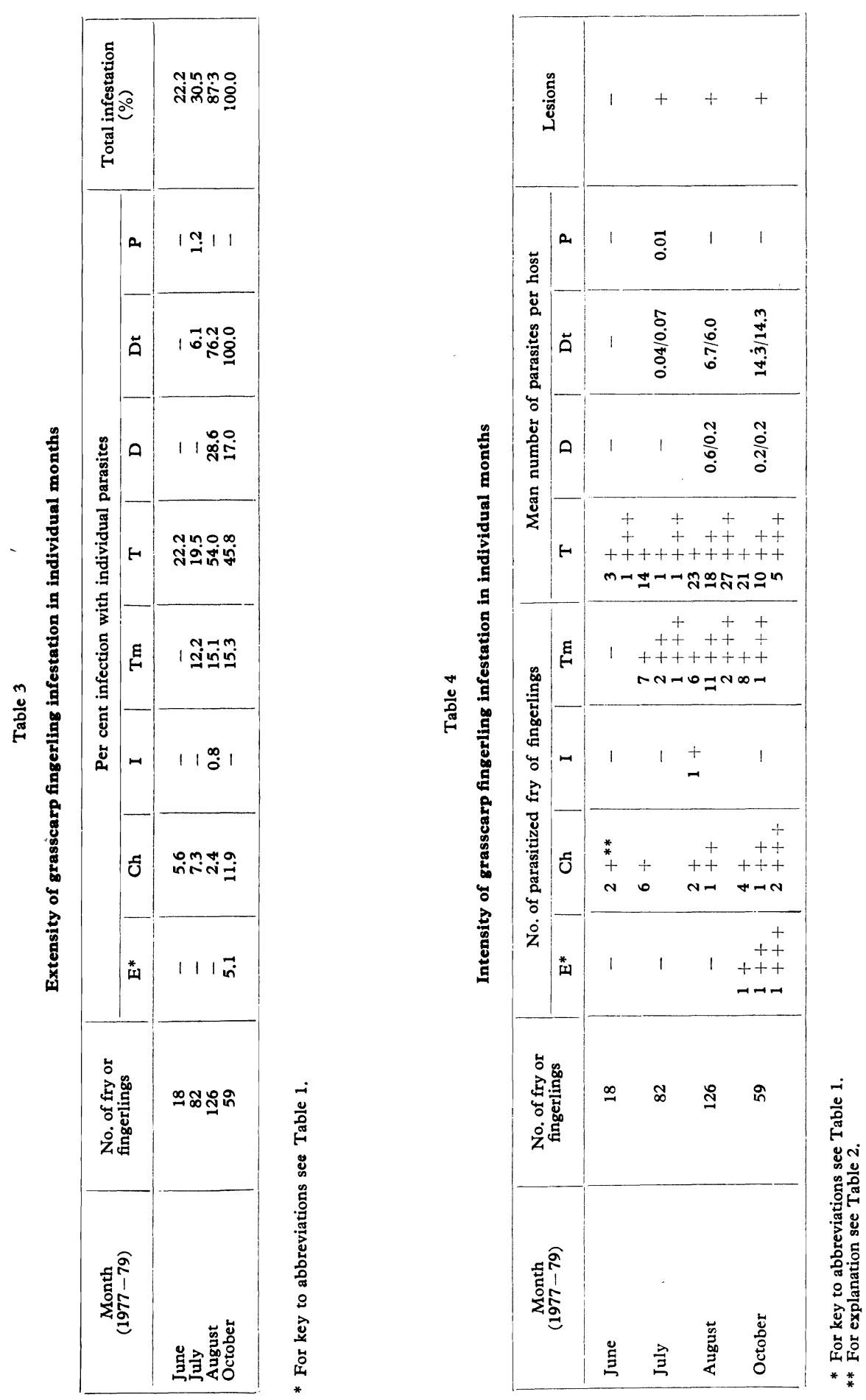
Of the parasitized organs only the eyes infested with Diplostomum metacercariae showed patho-anatomical changes, mainly purulent to necrotic in character and occassionally a complete calcification (in 6 to 10 per cent of the fish). The changes were often at variance with the intensity of infestation. Apparently a certain role can be ascribed to duration of the infection, since most lesions were observed in fingerlings aged 9,10 and 16 weeks. The highest number of Diplostomum metacercariae found in the eye of a grasscarp was 34 specimens.
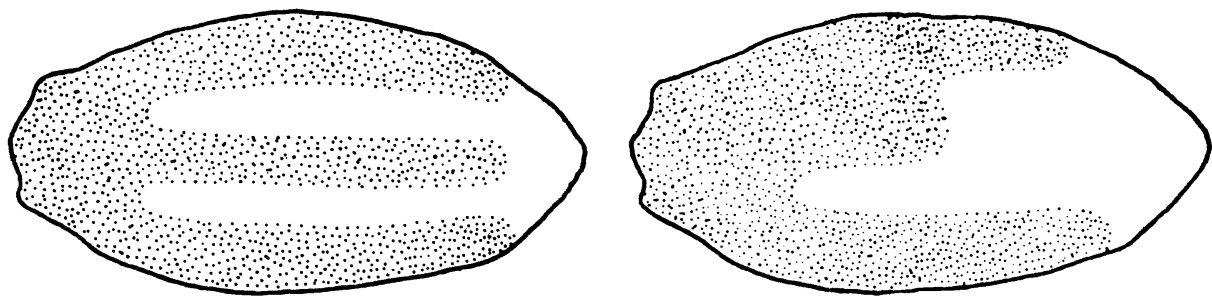

Fig. 2 and 3.

Distribution of calcium bodies in Diplostomum metacercariae (simplified scheme)

Table 5

Infestation of intermediate host snails with Diplostomum sp.

\begin{tabular}{|c|c|c|c|c|c|}
\hline \multirow{2}{*}{$\begin{array}{l}1978 / 79 \\
\text { Month }\end{array}$} & \multicolumn{4}{|c|}{ Per cent infestation of intermediate host snails } & \multirow{2}{*}{$\begin{array}{l}\text { Infection of } \\
\text { experimental fish } \\
\text { Lebistes ret. } \\
(\%)\end{array}$} \\
\hline & $\begin{array}{l}\text { Lymnaea } \\
\text { stangalis }\end{array}$ & $\begin{array}{c}\text { Lymnaea } \\
\text { auricularia }\end{array}$ & $\begin{array}{c}\text { Lymnaea } \\
\text { peregra }\end{array}$ & $\begin{array}{l}\text { Planorbis } \\
\text { corneus }\end{array}$ & \\
\hline $\begin{array}{l}\text { May } \\
\text { June } \\
\text { July } \\
\text { August } \\
\text { September } \\
\text { October }\end{array}$ & $\begin{array}{c}0 \\
34.6 \\
81.8 \\
100.0 \\
0 \\
80.0\end{array}$ & $\begin{array}{r}- \\
\overline{-} \\
100.0 \\
16.7 \\
100.0\end{array}$ & $\begin{array}{c}18.2 \\
- \\
- \\
62.5 \\
\overline{-} \\
100.0\end{array}$ & $\begin{array}{l}- \\
\overrightarrow{-} \\
\underline{0} \\
-\end{array}$ & $\begin{array}{c}0 \\
0 \\
\text { fish died } \\
80.0 \\
20.0 \\
50.0\end{array}$ \\
\hline
\end{tabular}

$0=$ negative.

$-=$ not examined.

It can be concluded that the most common parasitoses of crasscarp in the State Fishery at Pohořelice are chilodonellosis, trichodinellosis, dactylogyrosis and diplostomosis. Almost all causative agents of the parasitic diseases of grasscarp are transferred to grasscarp fingerlings from other fish species reared in polyculture in fingerling ponds.

\section{Discussion}

Lucký (1968) in his study on diseases of herbivorous fish drew attention to the possibility of parasite exchange between our traditional fish and newly introduced herbivorous fish. The present study confirmed this view by demonstrating that some of the parasite species harboured by our traditional fish are responsible, to a considerable degree, for losses among grasscarp fingerlings.

The evidence presented here suggests that the most common parasitoses among grasscarp fry are chilodonellosis, trichodinellosis and trichodinosis and that 
grasscarp fingerlings become affected with advancing age with additional parasitoses, mainly dactylogyrosis and diplostomosis. These parasitic diseases play also a role in the rearing losses among other economically important fish species.

The economic impact of fish loss due to Diplostomum metacercariae infections is considerable. In the present study Diplostomum metacercariae infection was found in all grasscarp fingerlings reared in fingerling ponds of the State Fishery at Pohořelice from the 9 th to the 16 th week after hatching and 6 to 10 per cent of the infested fish had extensive lesions in the eye. These fish do not take in food because of blindness, lose in body mass and eventually die. The mean body mass of grasscarp fingerlings examined was about $120 \mathrm{~g}$. If $1 \mathrm{~kg}$ yearling costs $20 \mathrm{Kčs}$, the annual loss due to Diplostomum infection per every 300000 grasscarp fingerlings amounts to 45 to 75 thousand Kčs.

The parasite range found in grasscarp fingerlings in the present study is somewhat different from that reported by Soviet writers (Agapova and Akhmetova 1966; Musselius 1969). This is quite understandable considering the different ecological conditions and the practice of grasscarp rearing in polyculture in Czechoslovakia. The results confirmed the view put forward by Vovk (1966) that the examination for, and control of, parasites that may have an adverse impact on fish farm economy should start in fingerling ponds.

\section{Sezónní dynamika parazitóz u plůdku amura bílého (Ctenopharyngodon idella)}

Během tř̌iletého vyšetřování plůdku bílého amura bylo zachyceno v odštěpném závodu Státního rybářství v Pohořelicích 12 rodů, resp. druhů cizopasníků. Intenzita a extenzita cizopasníků u plůdků byla nejvyšší v období od srpna do ř́ina. Od stáří plůdku 1 týdne byly zjištovány Chilodonella cyprini, Trichodinella sp. a Trichodina domerguei f. magna. Dále postupně se stářím plůdku se objevují invaze Diplostomum sp., Ichthyophthirius multifiliis, Dactylogyrus sp., Diplozoon paradoxum, Cryptobia branchialis, Eimeria sp., Piscicola geometra a Nematoda sp. Jako vzácnější výskyt byl potvrzen nález vývojového stadia tasemnice Cysticercus Gryporhynchus cheilancristrotus. Vztah stář́i - intenzita a extenzita invazí byl nejvíce zřetelný př̀i výskytu metacerkarií Diplostomum sp. Od stáŕí plůdku 9 týdnů bylo již $100 \%$ zamoření oční motolicí, přičemž intenzita invaze 3týdenního plůdku 1,4 jedincủ na hostitele stoupala úměrně se stárím plůdku na 34,7 u 6týdenního. Intenzita a extenzita metacerkarií motolice oční $\mathrm{u}$ ryb byla $\mathrm{v}$ průběhu sezóny ve vztahu $\mathrm{k}$ intenzitě a extenzitě cerkarií $\mathrm{v}$ mezihostitelských plžích.

\section{Сезонная динамика паразитозсв мальков Ctenopharyngodon idella}

В течение трехлетнего исследования мальков Ctenopharyngodon idella было установлено в филиале Государственного рыболовства в Погоржелицах 12 родов или видов паразитов. Интенсивность и әкстенсивность паразитов мальков была самой большой в перисд с августа по октябрь. В возрасте мальков одной недели были установлены Chilodonella cyprini, Trichodinella sp. и Trichodina domerguei f. magna. Постепенно с возрастом мальков появляются инвазии Diplostomum sp., Ichthyophthirius multifiliis, Dactylogyrus sp., Diplozoon paradoxum, Cryptobia branchialis, Eimeria sp., Piscicola geometra и Nematodasp. Реже был установлен первоначальный 
э'гап развития солитера Cysticercus Gryporhynchus cheilancristrotus. Соотношение возраст - интенсивность и экстенсивность инвазий более явно наблюдалось при наличии метацеркарий Diplostomum sp. У мальков с возраста 9 недель наблюдалось уже полное заражение глазной фасциолой, при этом интенсивность инвазии трехнедельного малька 1,4 индивидуума на хозяина паразитов увеличивалась пропорционально возрасту мальков на 34,7 у шестинедельного. Интенсивность и экстенсивность метацеркарий глазной фасциолы у рыб в течение сезона находилась в отношении к интенсивности и экстенсивности церкарий в гастроподах - промежуточных хозяевах.

\section{References}

AGAPOVA, A. I. - AKHMETOVA, B.: Parazity rastitelnojadnych ryb v Kazachstane. In: Bolezni ryb i mery borby s nimi. Alma-Ata 1966: 10-14.

BRICHUK. P. F.: Cryptobia cyprini Plehn, 1903 (Flagellata, Bodonidae) kak pričina gibeli belych amurov. Parazitologija, Leningrad, 3, 1969: 574-576.

BYKHOVSKIJ, B. E. et al.: Opredelitel parasitov presnovodnych ryb SSSR. Moskva-Leningrad 1962.

DYK, V.: Aklimatizované býložravé a síhovité ryby. Veterinářství, 25, 1975: 133-134.

HAVRÁNEK, M.: Druhové zastoupení metacerkarii rodu Diplostomum v chovech kaprů a býložravých ryb. (Studentská vědecká konference.) Brno 1978. Vysoká škola veterinární.

IVASIK, V. M. - KARPENKO, I. M.: Primenenie izvesti v borbe s ichtioftiriozom. Veterinarija, 43, 1966: 57.

IVASIK, V. M. - KULAKOVSKAJA, O.: Novi paraziti v jezernite stopanstva vov vrozka s aklimatiziraneto na dalekciztočnite ribi. Rib. Stopanstvo, 15, 1968, 8: 14 .

JÍROVEC, O.: Parazitologie pro lékaře. Praha 1948.

KLENOV, A. P.: Fenasal kak antgelmintik pri botriocefaleze belych amurov. In: Mater. nauč. Konferencii vses. Obšč. Gelmintol., Moskva 1971, 22: 107-109.

KOZÁK, A. - ŽITŇAN, R.: K metodike štúdia metacerkárií trematódov rodu Diplostomum Nordmann, 1832 u rýb. Biológia, 29, 1974, 8: 671-675.

LUCKÝ, Z.: Metodické návody $\mathrm{k}$ diagnostice nemocí ryb. Praha 1976.

LUCKÝ, Z.: Přehled nemocí býložravých ryb. Buletin VÚR Vodňany, 4, 1968: 28-36.

MÉSZÁROŠ, J.: Parazitofauna násady bieleho amura. Polov. Ryb., 23, 1971, 19: 19.

MIGALA, K.: Obserwacje nad inwazja pierwotniaków z rodzaju Cryptobia (Trypanoplasma) w układzie krwionošnym amura białego (Ctenopharyngodon idella Val.) hodowanego w stawach karpiowych. Roczn. Nauk roln., Ser. H, 1971, 3: 65-73.

MOLNÁR, K.: On diplostomosis of the grasscarp fry. Acta vet. hung., 24, 1974: 63-71.

MUSSELIUS, V. A.: Parazitarnye zabolevanija belych amurov, belych i pestrych tolstolobikov $\mathrm{v}$ prudovych chozjajstvach RSFSR. In: Bolezni ryb i mery borby s nimi. Alma-Ata 1966: 99-105.

MUSSELIUS, V. A.: Parazity rastitelnojadnych ryb dalnevostočnogo kompleksa pri vyraščivanii v prudovych chozjajstvach evropejskoj časti SSSR. Parazitologija, Leningrad, 3, 1969: $236-243$.

TOMÁNEK, J.: Průzkum parazitů plevelných ryb na jižní Moravě. (Thesis.) Brno 1952.

VOVK, P. S.: Ektoparazitofauna belogo amura i tolstolobika, vyraščivaemych v prudach USSR. In: Rybochozjajstvennoe osvojenie rastistelnojadnych ryb. Moskva: 1966: 104-108.

ŽITNAN, R.: Helminty aklimatizovaných rastlinožravých rýb na Slovensku. In: Sborník referátů $\mathrm{z}$ ichtyologické konference. Brno 1972: 94-103. 